\title{
Kahoot! or Quizizz: the Students' Perspectives
}

\author{
Yudi Basuki $^{1}$, Yeni Nurmala Hidayati ${ }^{2}$ \\ STKIP PGRI Trenggalek, Jl. Supriyadi 22 Trenggalek $^{1}$, \\ IIK Bhakti Wiyata Kediri, Jl. K.H. Wachid Hasyim 65 Kediri $^{2}$ \\ \{jude.q13@gmail.com¹,yeninurmal4@gmail.com ${ }^{2}$ \}
}

\begin{abstract}
Kahoot! and Quizizz are e-learning web-apps commonly used in conducting online quizzes. This research was aimed at: (1) knowing the students' perceptions of Kahoot! and Quizizz's efficacy in a daily online quiz, (2) figuring out the students' choices and (3) finding out their reasons. The research design was qualitative research concerning phenomenological studies with a sample of 250 students of English Education Department of STKIP PGRI Trenggalek. It used a close-ended questionnaire to collect the data of the students' perceptions. Data analysis of the questionnaires was analyzed quantitatively by implementing the Likert scale. Research findings of the first questionnaire toward Kahoot! and Quizizz's efficacy gained supportive responses with a total score of 15.484. The second questionnaire toward the students' choices and their reasons resulted in the total score 15.002 (Quizizz) and 12.248 (Kahoot!). In conclusion, Quizziz was more effective to foster students' enthusiasm for learning and better than Kahoot! for some reasons.
\end{abstract}

Keywords: Kahoot!, Quizizz, perception.

\section{INTRODUCTION}

Nowadays, quiz is one of the classroom activities that cannot be abandoned. It is a competition through a game which the students answer questions given by the teachers [1]. In today digital era, the advancement of ICT (Information and Communication Technology) has shifted the teaching-learning paradigm rapidly [2] [3]. Thus, e-learning has emerged from traditional learning that Kahoot! and Quizizz are kind of e-learning web-apps commonly used in conducting online quizzes in daily teaching-learning practices in the classroom.

Kahoot! is a platform that can make students able to collaborate as well as compete through interactive quiz-games [4]. It is as one of the media used as an ice-breaking session to carry online quizzes [5]. The recent study on Kahoot! purportedly offers a large number of advantages and enables teachers to be creative and students to be motivated, intrinsically and extrinsically [6]. Students were motivated to be attentive on the backdrop that they wanted to perform well in Kahoot!s. This, in turn, motivated students to engage with the lecturer, peers and lecture content. Kahoot! also motivated competition in the classroom, where students were driven to see their names at the top of the leaderboard, and thus, were more attentive during lectures and related discussions [7]. 
In affinity, Quizizz is one of many awesome tools for class quiz games [8]. Quizizz is as a fun multiplayer game platform or application classroom activity for quiz-games which students become a controller of their pace on game classroom activity [9]. Similar to Kahoot!, Quizizz also has some features are very salient more than Kahoot!. Quizizz provides students' answerpace to appear on each students' screen, so they can answer questions at their own pace and review their answer at the end [10]. Research on online quizzes as a teaching and assessment tool strictly conclude that the combination of quizzes with instructional activities/teaching strategies is favorable [11]. It helps students appertain to quiz appreciation, learning effort, learning motivation, activities involvement and academic achievement.

Due to the inclusion of Information and Communication Technology (ICT) in education and in making students enthusiastic, the English Education Department of STKIP PGRI Trenggalek has been attempting to implement Kahoot! and Quizizz in TLP especially in conducting quizzes. However, the implementation of those e-learning web-apps have not been figured out their efficacy and which one is better in making students' motivated based on the students' perspectives. Although, Kahoot! and Quizizz have slightly different features; the lecturers remain using them as e-learning web-app variations to quizzes in TLP.

With regards to some research reports on Kahoot! and Quizizz and in an attempt to prove out and compare the efficacy of Kahoot! and Quizizz, the present research tries to answer the following questions: (1) how are the students' perceptions of the Kahoot! and Quizizz's efficacy in their daily online quizzes?, (2) which one of the two e-learning web-apps (Kahoot! and Quizizz) do they think better?, and (3) Why do the students think so?

\section{METHODOLOGY}

The researchers utilized a qualitative research method concerning a phenomenological study to address the three research questions. A phenomenological study is designed to describe and interpret experience by determining the meaning of it as perceived by the people who have participated [12].

This research involved 250 students of English Education Department of STKIP PGRI Trenggalek, East Java, Indonesia by the end of the odd semester in the 2018/2019 AY. The students consisted of 182 females and 68 males taking lectures implemented Kahoot! and Quizizz in their daily online quizzes once a week of each platform, within one semester. Thus, the students had 14 Kahoot!s and 14 Quizizzs on average in one semester. Also, the web-app online quizzes (Kahoot! and Quizizz) were done in the multimedia laboratory, so there was not any issue concerning the internet connections.

The researchers collected the data of the students' perceptions of the Kahoot! and Quizizz's efficacy in their daily online quizzes, their choice between Kahoot! and Quizizz and the reasons for the choice from questionnaires. The questionnaires were divided into two; to have a depiction of the students' perceptions of the Kahoot! and Quizizz's efficacy in their daily online quizzes, and to figure out the students' choice between Kahoot! and Quizizz, and find out the reasons for the students' choice as well. Meanwhile, the perception in this research carries the meaning of the experience of the object, events, or the relationships obtained by inferring the information and interprets the message with the help of the senses [13] [14] [15].

Further, to assess the validity and reliability of the instruments, the researchers had piloted them before they were implemented to all of the students. By incorporating the Pearson Product Moment correlation at $5 \%$ level of significance $(\alpha)$, the researchers randomly took 60 students as the samples to test the validity of 45 items of the questionnaire. As a result, the coefficient of Pearson Product Moment correlation resulted from rC (count) 0.254 which was higher than the rT (table). Further, the reliability of the instruments was tested by incorporating Alpha Cronbach 
Formula. The result of the reliability test of 60 question items was 0.974 . The questions (instruments), they are said reliable if their Alpha Cronbach's score is higher than 0.7. Therefore, the research instruments were valid and reliable.

To analyze the collected data from the questionnaires, the researchers made use of Likert scale requiring the respondents' perceptions and/or opinions in the form of five statements [16]; Strongly Agree (SA), Agree (A), Neutral (N), Disagree (D), and Strongly Disagree (SD) of the 250 students toward Kahoot! and Quizizz's efficacy (Q1), their choice between Kahoot! (K) and Quizizz (Q) and the reasons for the choice (K or Q).

Then, the researchers carried out the following procedures in analyzing data from the Likert Scale. First, scoring each item in the scale; 5 (SA), 4 (A), 3 (N), 2 (D) and 1 (SD). Second, calculating the score range for each set of questionnaire as follows; maximum score $(\mathrm{Q} 1 / \mathrm{K} / \mathrm{Q})=$ $250 \times 5=1250 \times 15=18.750$, Minimum score $(\mathrm{Q} 1 / \mathrm{K} / \mathrm{Q})=250 \times 1=250 \times 15=3.750$ and Score range $(\mathrm{R})(\mathrm{Q} 1 / \mathrm{K} / \mathrm{Q})=18.750-3.750=15.000$. Third, determining the criteria of score interpretation of each questionnaire set;

Table 1. Total Score Interpretation

\begin{tabular}{cc}
\hline Score Q1/K/Q & Interpretation \\
\hline $\mathbf{1 8 . 7 5 0}-\mathbf{1 5 . 0 0 1}$ & Strongly agree \\
\hline $\mathbf{1 5 . 0 0 0}-\mathbf{1 1 . 2 5 1}$ & Agree \\
\hline $\mathbf{1 1 . 2 5 0}-\mathbf{7 . 5 0 1}$ & Neutral \\
\hline $\mathbf{7 . 5 0 0}-\mathbf{3 . 7 5 1}$ & Disagree \\
\hline $\mathbf{3 . 7 5 0}$ & Strongly disagree \\
\hline
\end{tabular}

Fourth, drawing a continuum diagram for the score interpretation as the following:

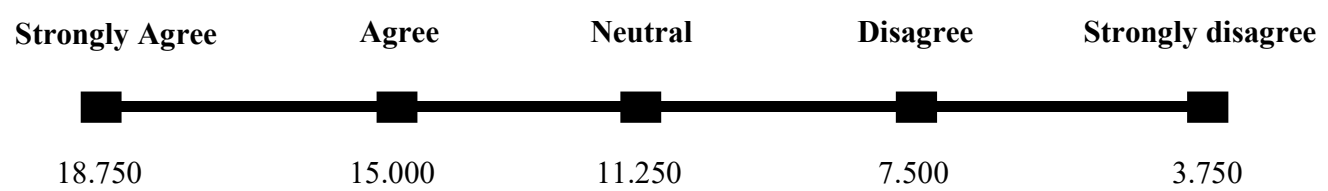

Figure 1. Continuum Diagram

\section{FINDINGS AND DISCUSSION}

Table 2 and figure 2 below summarize the result the students' perceptions of Kahoot! and Quizizz's efficacy in their daily online quizzes.

Table 2. Students' perceptions of Kahoot! and Quizizz's efficacy in their daily online quizzes (Q1)

\begin{tabular}{|c|c|c|c|c|c|c|c|}
\hline & ITEM & 1 (SD) & 2 (D) & $3(N)$ & $4(\mathrm{~A})$ & 5 (SA) & $\begin{array}{l}\text { Item } \\
\text { Score }\end{array}$ \\
\hline 1 & $\begin{array}{l}\text { I find Kahoot! and Quizizz exciting, interesting, } \\
\text { motivating \& fun. }\end{array}$ & 2 & 6 & 32 & 113 & 97 & 1047 \\
\hline 2 & I look forward to playing Kahoot! and Quizizz & 7 & 7 & 87 & 134 & 15 & 893 \\
\hline 3 & I feel positive when playing Kahoot! and Quizizz & 4 & 3 & 49 & 93 & 101 & 1034 \\
\hline 4 & $\begin{array}{l}\text { I focus on the questions in each Kahoot! and Quizizz } \\
\text { session. }\end{array}$ & 4 & 6 & 11 & 162 & 67 & 1032 \\
\hline 5 & $\begin{array}{l}\text { I respond to each question in each Kahoot! and } \\
\text { Quizizz session. }\end{array}$ & 4 & 11 & 84 & 80 & 71 & 953 \\
\hline 6 & $\begin{array}{l}\text { I respond as quickly as possible to each question in } \\
\text { each Kahoot! and Quizizz session. }\end{array}$ & 7 & 6 & 4 & 21 & 212 & 1175 \\
\hline
\end{tabular}




\begin{tabular}{|c|c|c|c|c|c|c|c|}
\hline 7 & $\begin{array}{l}\text { I respond as accurately as possible to each question in } \\
\text { each Kahoot! and Quizizz session. }\end{array}$ & 3 & 5 & 17 & 200 & 25 & 989 \\
\hline 8 & $\begin{array}{l}\text { I like the collaboration \& competitiveness in Kahoot! } \\
\text { and Quizizz sessions }\end{array}$ & 3 & 7 & 4 & 76 & 160 & 1133 \\
\hline 9 & $\begin{array}{l}\text { I am motivated to win all these Kahoot! and Quizizz } \\
\text { sessions. }\end{array}$ & 9 & 6 & 7 & 111 & 117 & 1071 \\
\hline 10 & $\begin{array}{l}\text { I pay more attention during lectures because I hope to } \\
\text { win in the Kahoot! and Quizizz sessions. }\end{array}$ & 8 & 12 & 13 & 59 & 158 & 1097 \\
\hline 11 & I am eager to learn via Kahoot! and Quizizz & 12 & 10 & 18 & 83 & 127 & 1053 \\
\hline 12 & $\begin{array}{l}\text { I prepare better to win in the Kahoot! and Quizizz } \\
\text { sessions }\end{array}$ & 18 & 21 & 18 & 132 & 61 & 947 \\
\hline 13 & $\begin{array}{l}\text { Kahoot! and Quizizz create an energetic classroom } \\
\text { atmosphere }\end{array}$ & 6 & 6 & 21 & 108 & 109 & 1058 \\
\hline 14 & I don't want to miss any Kahoot! and Quizizz sessions & 11 & 13 & 9 & 155 & 62 & 994 \\
\hline \multirow[t]{4}{*}{15} & $\begin{array}{l}\text { Kahoot! and Quizizz must be used in daily online } \\
\text { quizzes }\end{array}$ & 13 & 9 & 30 & 103 & 95 & 1008 \\
\hline & TOTAL SCORE & 111 & 128 & 404 & 1630 & 1477 & \\
\hline & TOTAL Score X Option Value $(1,2,3,4,5)$ & 111 & 256 & 1.212 & 6.520 & 7.385 & \\
\hline & TOTAL SCORE Kahoot! and Quizizz & & & 15.484 & & & \\
\hline
\end{tabular}

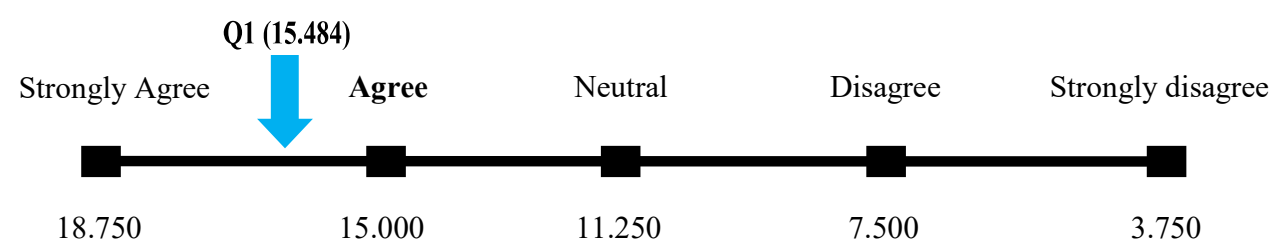

Figure 2. Continuum Diagram of Kahoot! and Quizizz's efficacy (Q1)

By referring to the table 2 and figure 2, it proved that the incorporating Kahoot! and Quizizz as web-apps in the students daily online quizzes was effective. Fortunately, the need for Kahoot! and Quizizz in the students' daily online quizzes was one point on which they do really agree. It resulted in a total score of 15.484 in the 'strongly agree' range of the score interpretation. From the given table, the questionnaire item number 6 got the most supportive response from the students (1175, strongly agree). It implied the students were challenged to compete by answering the questions as fast as possible to lead the leaderboard. It was also supported by the questionnaire item number 8 (1133, strongly agree) as the $2^{\text {nd }}$ highest score which says "I like the collaboration \& competitiveness in Kahoot! and Quizizz sessions". Meanwhile, the lowest score was gained by the questionnaire item number 2 (893, Agree/nearly neutral) which says I "look forward to playing Kahoot! and Quizizz". It implied that the students were eager to have other Kahoot!s and Quizizzs in the next quizzes sessions, however, if it is seen in a different view as the lowest score and since the inclusion of Kahoot! and Quizizz in the next quizzes sessions, here, the item result number 2 strengthened the second research aim to be answered which was to figure the students' choice between Kahoot! and Quizizz.

Regarding table 2 and figure 2 as a partial result of the present research, it is not hesitant to say that the implementation of Kahoot! and Quizizz as the daily online quizzes brings an overwhelming efficacy. This result has supported and strengthened other researches on the inclusion of ICT in TLP. However, the present research once proved that Kahoot! and Quizizz are engaging, addicting and motivating the students. Kahoot! and Quizizz make them pay more attention during lectures in the classroom as well as their autonomous learning at home. They 
enhance the students' classroom participation, collaboration \& competitiveness. The students continuously pertained to their focus in Kahoot! and Quizizz thus they strongly agree that Kahoot! and Quizizz are the must-have web-apps in organizing online quizzes.

Meanwhile, the following table 3 and 4 and figure 3 display the summary of the Students' perceptions of Kahoot! and Quizizz in their daily online quizzes (K and Q) and the comparison of the total score in the Continuum Diagram of Kahoot! (K) and Quizizz (Q).

Table 3. Students' perceptions of Kahoot! in their daily online quizzes (K)

\begin{tabular}{|c|c|c|c|c|c|c|c|}
\hline \multicolumn{2}{|r|}{ ITEM } & \multirow{2}{*}{$\begin{array}{c}1 \text { (SD) } \\
3\end{array}$} & \multirow{2}{*}{$\begin{array}{c}2 \text { (D) } \\
6\end{array}$} & \multirow{2}{*}{$\begin{array}{c}3(\mathbf{N}) \\
42\end{array}$} & \multirow{2}{*}{$\begin{array}{c}4 \text { (A) } \\
156\end{array}$} & \multirow{2}{*}{$\begin{array}{c}5 \text { (SA) } \\
43\end{array}$} & \multirow{2}{*}{$\begin{array}{c}\text { Item } \\
\text { Score } \\
980\end{array}$} \\
\hline 1 & $\begin{array}{l}\text { I find Kahoot! exciting, interesting, motivating } \\
\& \text { fun }\end{array}$ & & & & & & \\
\hline 2 & I look forward to playing Kahoot! & 11 & 24 & 90 & 97 & 28 & 857 \\
\hline 3 & I feel positive when playing Kahoot! & 9 & 11 & 84 & 116 & 30 & 897 \\
\hline 4 & $\begin{array}{l}\text { I like the collaboration \& competitiveness in } \\
\text { Kahoot! sessions }\end{array}$ & 3 & 7 & 4 & 169 & 67 & 1040 \\
\hline 5 & I am eager to learn via Kahoot! & 4 & 8 & 44 & 148 & 46 & 974 \\
\hline 6 & $\begin{array}{l}\text { Kahoot! create an energetic classroom } \\
\text { atmosphere }\end{array}$ & 7 & 7 & 31 & 160 & 45 & 979 \\
\hline 7 & $\begin{array}{l}\text { Kahoot! tends to be under students' control } \\
\text { (Students directed/paced) }\end{array}$ & 67 & 76 & 81 & 20 & 6 & 572 \\
\hline 8 & $\begin{array}{l}\text { Kahoot! is quite (concentration/focus } \\
\text { disturbance) }\end{array}$ & 39 & 57 & 77 & 48 & 29 & 721 \\
\hline 9 & Kahoot! doesn't give any chance to cheat & 47 & 67 & 67 & 39 & 30 & 688 \\
\hline 10 & Kahoot! final leaderboard satisfies you & 13 & 26 & 121 & 42 & 48 & 836 \\
\hline 11 & Kahoot! has some special challenging features & 20 & 29 & 83 & 69 & 49 & 848 \\
\hline 12 & $\begin{array}{l}\text { I find Kahoot! reveal the real students' } \\
\text { competence }\end{array}$ & 47 & 36 & 100 & 37 & 30 & 717 \\
\hline 13 & I feel Kahoot! familiar and simple to do & 15 & 18 & 90 & 85 & 42 & 871 \\
\hline 14 & Kahoot! feedback for questions is engaging & 38 & 78 & 66 & 49 & 19 & 683 \\
\hline \multirow[t]{4}{*}{15} & Kahoot! is better than Quizizz & 46 & 83 & 111 & 10 & 0 & 585 \\
\hline & TOTAL SCORE & 369 & 533 & 1091 & 1245 & 512 & \\
\hline & TOTAL Score X Option Value $(1,2,3,4,5)$ & 369 & 1066 & 3273 & 4980 & 2560 & \\
\hline & TOTAL SCORE Kahoot! & & & 12248 & & & \\
\hline
\end{tabular}

Table 4. Students' perceptions of Quizizz in their daily on line quizzes (Q)

\begin{tabular}{|c|c|c|c|c|c|c|c|}
\hline & ITEM & 1 (SD) & 2 (D) & $3(\mathbf{N})$ & $4(\mathrm{~A})$ & 5 (SA) & $\begin{array}{l}\text { Item } \\
\text { Score }\end{array}$ \\
\hline 1 & $\begin{array}{l}\text { I find Quizizz exciting, interesting, motivating } \\
\text { \& fun }\end{array}$ & 3 & 6 & 18 & 80 & 143 & 1104 \\
\hline 2 & I look forward to playing Quizizz & 6 & 12 & 24 & 63 & 145 & 1079 \\
\hline 3 & I feel positive when playing Quizizz & 9 & 11 & 29 & 109 & 92 & 1014 \\
\hline 4 & $\begin{array}{l}\text { I like the collaboration \& competitiveness in } \\
\text { Quizizz sessions }\end{array}$ & 27 & 57 & 79 & 71 & 16 & 742 \\
\hline 5 & I am eager to learn via Quizizz & 5 & 7 & 18 & 78 & 142 & 1095 \\
\hline 6 & $\begin{array}{l}\text { Quizizz create an energetic classroom } \\
\text { atmosphere }\end{array}$ & 5 & 21 & 44 & 94 & 86 & 985 \\
\hline 7 & $\begin{array}{l}\text { Quizizz tends to be under students' control } \\
\text { (Students directed/paced) }\end{array}$ & 4 & 13 & 22 & 88 & 123 & 1063 \\
\hline 8 & $\begin{array}{l}\text { Quizizz is quite (concentration/focus } \\
\text { disturbance) }\end{array}$ & 7 & 27 & 33 & 92 & 91 & 983 \\
\hline 9 & Quizizz doesn't give any chance to cheat & 5 & 5 & 23 & 127 & 90 & 1042 \\
\hline
\end{tabular}




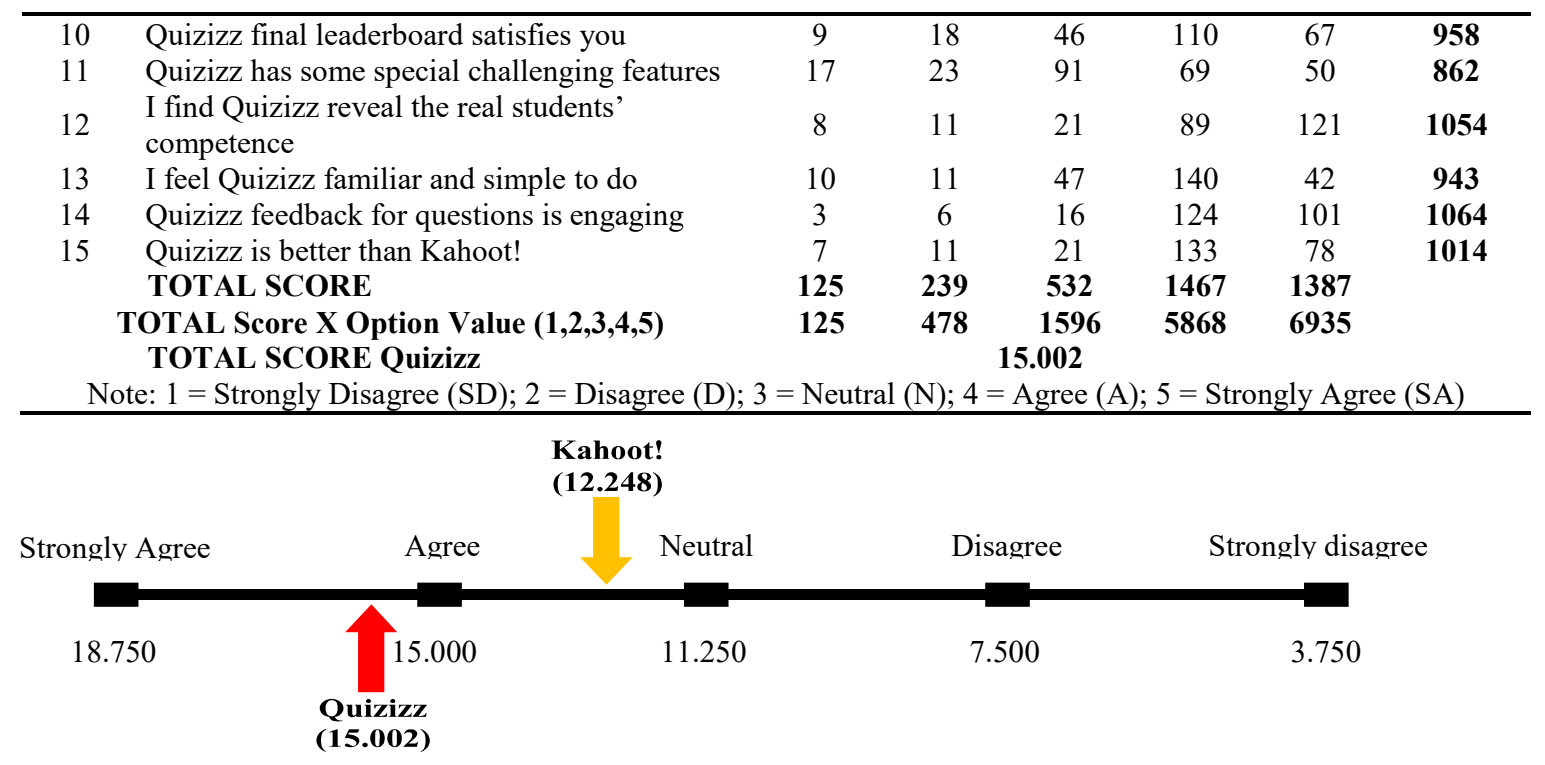

Figure 3. Continuum Diagram of Kahoot! (K) and Quizizz (Q) Total Score

According to table 3 and 4 and figure 3, Kahoot! resulted total score of 12.248 and Quizizz scored 15.002. There was a slight difference with 2.754 range between Kahoot! and Quizizz. However, the slight range between Kahoot! and Quizizz were able to reveal the students' preference for Quizizz over Kahoot!. Focusing on the last questionnaire item of each in which explicitly states "Kahoot! is better than Quizizz" and the contrary, the Kahoot! has gained a total score of 585 and the Quizizz 1014. Hence, the students believe that Quizizz is a better choice for the web-app online quizzes than Kahoot!.

To explain further, regarding to table 3 and 4; item comparison between Kahoot! $(\mathrm{K})$ and Quizizz (Q), here some reasons reveal the students' preference for Quizizz over Kahoot!. First, Quizizz is more exciting, interesting, motivating \& fun $(\mathrm{Q} 1=1104, \mathrm{~K} 1=980)$; second, Quizizz is more addictive $(\mathrm{Q} 2=1079, \mathrm{~K} 2=857)$; third, Quizizz make students more confident/positive (Q3 = 1014, K3 = 897); fourth, Quizizz is more eager (Q5 = 1095, K5 = 974); fifth, Quizizz creates more energetic classroom atmosphere $(\mathrm{Q} 6=985, \mathrm{~K} 6=979)$; sixth, Quizizz allows students to finish the quiz more independently $(\mathrm{Q} 7=1063, \mathrm{~K} 7=572)$; seventh, Quizizz makes students more focus in doing the quiz $(\mathrm{Q} 8=983, \mathrm{~K} 8=721)$; eight, Quizizz results more fair and objective score $(\mathrm{Q} 9 / 10 / 12=1018, \mathrm{~K} 9 / 10 / 12=747)$; , ninth, Quizizz is more familiar and simpler (no need more body movements) $(\mathrm{Q} 13=943, \mathrm{~K} 13=871$ ); lastly, the tenth, Quizizz questions feedbacks (memes) are more engaging $(\mathrm{Q} 14=1014, \mathrm{~K} 14=683)$.

Despite all reasons why Quizizz is better than Kahoot!, the findings of the research had also proven a students' preference for Kahoot! over Quizizz and some students' nearly the same preferences. Kahoot! is more collaborative \& competitive $(\mathrm{Q}=742, \mathrm{~K}=1040)$, then, Kahoot! is as energetic as Quizizz, Kahoot! has some same special challenging features with Quizizz, and Kahoot! is as familiar as Quizizz.

Given the results of the research, it is noteworthy to discuss with the related theories. As mentioned by a recent study on ICT, the functions of ICT in education especially for students are replacing the orthodox method of teaching-learning, to be an effective assisting tool to write assignments, collecting data and search engine for research, making students as an independent 
learner, providing the platform for online discussion and free consultation with subject experts, making the real classroom and source to run a global varsity by the global teacher to the global students [17]. Meanwhile, it has proven that the students made a positive perception of the effectiveness of online quizzes towards language skills and components [18]. They find the student positively appreciate the online quizzes' feedback; the students are motivated and encouraged.

Moreover, the presence of the quizzes was essential to help students to be in contact with the subject, and to feel more confident to take the quizzes. Similarly, the present research has proved that incorporating Kahoot! and Quizizz brings overwhelming efficacy. Fortunately, the need for Kahoot! and Quizizz in the students' daily online quizzes was one point on which they do really agree. However, the present research once also has proven that Kahoot! and Quizizz are engaging, addicting and motivating the students to learn and achieve more. In line with it, motivated learners tend to show a favorable attitude toward the subject, engage and interest to shows favorable attitude and will to exert the goal of learning [19].

To discuss further, is Quizizz better than Kahoot? Some reasons why Quizizz is better than Kahoot for the students [8] [9] [20]. First is the engagement; Quizizz is more engaging for it does not split the students' concentration during the quiz. It allows the students to see the questions and all possible answers on their own devices and it is likely students self - directed quiz which the students might complete the quiz at their own speed and therefore remain highly engaged during the quiz. Second, a more fair result; questions and answers are shuffled for each student. Therefore they have no chance to cheat each other. Third, since the questions and answers are shuffled for each student, they keep focusing on doing their own work. Fourth, more entertaining. Quizizz has memes, funny pictures shown after each question, as the questions' feedbacks. In these lines, from the students' view as the result of the present research, students' preference for Quizizz over Kahoot! has some reasons. First, Quizizz is more interesting, motivating and fun. Second, Quizizz is more addictive. Third, Quizizz makes students more confident/positive. Fourth, Quizizz makes students more eager to grasp the lessons in the classroom or autonomous learning at home. Fifth, Quizizz creates a more energetic classroom atmosphere. Sixth, Quizizz allows students to finish the quiz more independently. Seventh, Quizizz makes students more focus on doing the quiz. Eight, Quizizz results from a more fair and objective score. Ninth, Quizizz is more familiar and simpler (no need more body movements). Lastly, the tenth, Quizizz questions' feedbacks (memes) are entertaining.

\section{CONCLUSIONS}

Hence, the conclusion hold is incorporating Kahoot! and Quizizz as the inclusion of ICTs or web-apps in the students daily online quizzes brings an overwhelming efficacy, Quizizz is better than Kahoot and the students' preference for Quizizz over Kahoot! has some reasons. The need for Kahoot! and Quizizz in the students' daily online quizzes was one point on which they do really agree. Kahoot! and Quizizz are engaging, addicting and motivating the students to learn and achieve better. However, from the students' view, the absence of Kahoot!'s features make them not a better choice than Quizizz. The one and the principal point that makes Kahoot! is not a better choice than Quizizz is its application that also affects others. Kahoot! is designed to show multiple choice questions on a large screen, and the students respond by clicking buttons on their devices that correspond to the answers they want to choose all at the same time with the same questions and possible answers. Kahoot! can get a little nasty when everyone looking on the screen and celebrating at the same time. However, this design might unite the lesson and encourage players to look up. So, if the goal is active classroom engagement, then Kahoot is probably the better choice. Despite all reasons why Quizizz is better than Kahoot!, the findings 
of the research proved the students' preference for Kahoot! over Quizizz which Kahoot! is more collaborative \& competitive. Kahoot!'s feature (live game - team mode) allows the students to lively collaborate and compete among groups in an energetic classroom atmosphere as well.

\section{References}

[1] E. Walter, Cambridge Advanced Learner's Dictionary, Third Edition. Cambridge: Cambridge University Press, 2008.

[2] O. Uysal and A. Kuzu, "A Thesis Proposal: Quality Standards of Online Higher Education in Turkey," Proceedings of the 2009 EMUNI Conference on Higher Education an Research, September 25-26, 2009.

[3] M. Jamil, R.H. Tariq, P.A. Shami, "Computer-Based vs. Paper-Based Examinations: Perceptions of University Teachers," TOJET: The Turkish Online Journal of Educational Technology, Vol. 11, no.4, pp. 371-381, October 2012.

[4] F. Rofiyarti and A.Y. Sari, Jurnal Anak Usia Dini dan Pendidikan Anak Usia Dini. Vol. 3, no.3, pp. 99-112, 2017.

[5] S. Darma, Students' Perception of the Use of Kahoot! as an Ice Breaker in Interpretation Class, Yogyakarta: Sanata Dharma University, 2016.

[6] D. Lin, M. Ganapathy, K. Manjet, "Kahoot! It: Gamification in Higher Education," Pertanika Journal of Social Sciences \& Humanities, vol. 26, no.1, pp. 565 - 582, 2018.

[7] S.A. Licorish, K.D. Ben, O. Helen, "Go Kahoot! Enriching Classroom Engagement, Motivation and Learning Experience with Games," 2017. [Online]. Available: https://www.researchgate.net/publication/322150947 [accessed January 8, 2019]

[8] T. Vincent, "Class Quiz Games with Quizizz (an Alternative to Kahoot)," 2015. [Online]. Available: https://learninginhand.com/blog/quiziz [accessed January 11, 2019]

[9] S.Reid, "Why Quizizz is better than Kahoot?," 2016. [Online]. Available: https://medium.com/@Stephen_Reid/why-quizizz-is-better-than-kahoot-9d585cblee3e [accessed December 12, 2018]

[10] E. Brunat, "6 Reasons why Quizizz is better than Kahoot," 2018. [Online]. Available: https://estherbrunat.com/2018/01/21/6-reasons-why-quizizz-is-better-than-kahoot [accessed February 19, 2019]

[11] L.S.Morera, A.A. Antonio, G.H. Laura, Journal of Technology and Science Education. Vol.2, no.1, pp.39-45, 2012.

[12] D.J. Ary, L.C. Sorenson, A. Razafieh, Introduction to Research in Education. United States of America: Wadsworth, Cengage Learning, 2010.

[13] Otnamhafira, "Persepsi," 2010. https://otnamhafira.wordpress.com/2010/02/18/persepsi [accessed February 21, 2019]

[14] Riadi, "Pengertian Persepsi," 2012. [Online]. Available: http://www.kajianpustaka.com/2012/10/teori-pengertian-proses-faktor-persepsi.html?m=1 [accessed February 21, 2019]

[15] J. Rahmat, Psikologi Komunikasi, Bandung: PT. Remaja Rosdakarya Offset, 2007.

[16] Riduwan, Metode dan Teknik Menyusun Tesis. Bandung: Alfabeta, 2008.

[17] P. Madhavan, "The Information and Communication Technology (ICT) and English teaching in polytechnic colleges, "International Journal of Advanced Research, Ideas, and Innovations in Technology," vol.4, no.4, pp. 609-610, 2018.

[18] P. Llorente, et al., "The use of online quizzes for continuous assessment and self-assessment of second-language learners," Proceedings of the Fourth International Conference on 
Technological Ecosystems for Enhancing Multiculturality (TEEM'16), pp.819-824, November 2-4, 2016.

[19] Y. Basuki, "The Use of Peer-Assessment of Reading Aloud to Improve the English Department Students' motivation on Pronunciation Class of STKIP PGRI Trenggalek," Jurnal Pendidikan Dewantara, Vol.2, no.1, pp.41-61, 2016.

[20] E. Brunat, "6 Reasons why Quizizz is better than Kahoot," 2018. [Online]. Available: https://estherbrunat.com/2018/01/21/6-reasons-why-quizizz-is-better-than-kahoot [accessed February 21, 2019]

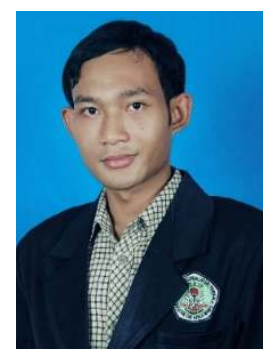

\section{1st AUTHOR BIODATA}

Yudi Basuki was born in Trenggalek, East Java, on July 22, 1985, to Ibu Suhartatik and Ayah the late M.Faris. He is married to Yeni Nurmala Hidayati, a lecturer of IIK Bhakti Wiyata Kediri. His formal education is started from SDN Bodag II Panggul (graduated in 1998), SMPN 1 Trenggalek (graduated in 2001), SMKN 3 Boyolangu Tulungagung (machinery, graduated in 2004) to a bachelor degree in English education of STKIP PGRI Tulungagung (graduated in 2010). He finished his master degree in English education from Universitas Islam Malang in 2012. From 2010 up to the present, he has been a lecturer of English in STKIP PGRI Trenggalek. In 2017, with Drs. Fahrudin, M.Pd., he published his first book entitled "Dictionary of English - Indonesian Terminology: Health and Medical Edition". Some of his published research articles are The Use of Peer Assessment of Reading Aloud To Improve The Students' Motivation on Pronunciation Class (2016), The Requisite Vocabulary I Material For College Students of English Education Department (2017), The Use of Drilling Method To Improve Students Phonetic Transcription And Word Stress Mastery (2018), Analyzing EFL learners needs for vocabulary learning materials (2018) and Vocabulary Coursebook for EFL Learners of Higher Education in Indonesia (2018). In 2018, he successfully published his second book entitled "Buku Ajar Vocabulary 2: Bridging Language Acquisitions from basic. In 2017, he became a keynote speaker in an international seminar "Understanding the Global Business Competition Though Leadership, English and Transformation of Students' Mindset" with other keynote speakers from USA, UK, Singapore, Nepal and Indonesia. At the end of 2018, he was invited as a speaker in an international conference; ICRTEL $5^{\text {th }}$ (International Conference on Research in Teaching Education and Learning) held in NUS (The National University of Singapore) in Singapore.

\section{$2^{\text {nd }}$ AUTHOR BIODATA}

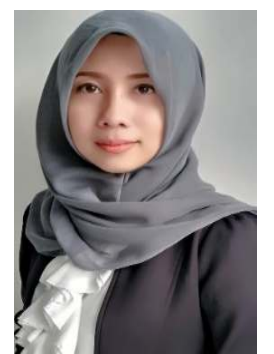

Yeni Nurmala Hidayati was born on January 10, 1986, in Trenggalek, East Java, Indonesia. She is the third child of Soerachmo (now deceased) and Sri Hartati. She is married to Yudi Basuki, a lecturer in English Education Department of STKIP PGRI Trenggalek and a proud mother to her son, Nayotama. She graduated from State Senior High School 1 Trenggalek in 2004 and continued her study to STKIP PGRI Tulungagung, majoring in English Education Department. In 2016, she officially graduated from Islamic University of Malang (UNISMA), majoring in Magister of English Education.

From May 2016 up to the present, she has dedicated herself as an English lecturer in Institut Ilmu Kesehatan Bhakti Wiyata in Kediri. Her educational background has given her a chance to run 
the Language Center in this college since April 2018. English Teaching, English for Specific Purposes, Research and Development have been her interest and enthusiasm. She contributed her first article entitled ESP Materials for Medical Records Students: an Evaluation Study in Lingua Litera, the journal of English teaching, learning and literature in November 2018. 